\title{
ВЛИЯНИЕ МОРФОЛОГИИ НЕТКАНЫХ УЛЬТРАВОЛОКНИСТЫХ МАТЕРИАЛОВ ПОЛИГИРОКСИБУТИРАТА НА ВЗАИМОДЕЙСТВИЕ С ОЗОНОМ
}

\author{
А.А. Ольхов, П.М. Тюбаева, А. С. Курносов, А.А. Попов, \\ В. В. Подмастерьев, А. Л. Иорданский
}

\begin{abstract}
АНАТОЛИЙ АЛЕКСАНДРОВИЧ ОЛЬХОВ - к.т.н., доиент, в.н.с. РЭУ им. Г.В. Плеханова, с.н.с. ИБХФ РАН. Область научных интересов: структура, физико-химические свойства и технология полимеров, композитов и биополимерныхкомпозитов.E-mail: aolkhov72@yandex.ru.
\end{abstract}

ПОЛИНА МИХАЙЛОВНА ТЮБАЕВА - магистр, инженер иентра коллективного пользования РЭУ им. Г.В. Плеханова, м.н.с. ИБХФ РАН. Область научных интересов: структура, физико-химические свойства и технология полимеров, композитов и биополимерных композитов.

АЛЕКСАНДР СЕРГЕЕВИЧ КУРНОСОВ - магистр химии и технологии, аспирант ИБХФ РАН. Область научных интересов: структура, физико-химические свойства и технология полимеров, композитов и биополимерных композитов.

АНАТОЛИЙ АНАТОЛЬЕВИЧ ПОПОВ - д.х.н., профессор, зам. директора ИБХФ РАН, заведуюший кафедрой РЭУ им. Г.В. Плеханова. Область научных интересов: физикохимия полимеров и полимерных композитов.

ВЯЧЕСЛАВ ВАСИЛЬЕВИЧ ПОДМАСТЕРЬЕВ - к.х.н., с.н.с. ИБХФ РАН. Область научных интересов: структура, окисление и озонолиз полимерных материалов.

АЛЕКСЕЙ ЛЕОНИДОВИЧ ИОРДАНСКИЙ - д.х.н., в.н.с. ФИЦ ХФ РАН. Область научных интересов: структура, диффузионные и физико-химические свойства полимеров и композитов.

117997 Москва, Стремянный пер., 36. Российский экономический университет им. Г.В. Плеханова.

119334, Москва, ул. Косыгина, 4. Институт биохимической физики им. Н.М. Эммануэля РАН.

119991, Москва, ул. Косыгина, 4. Федеральный исследовательский центр химической физики им. Н.Н. Семенова РАН.

Методом электроформования в работе получены образиы нетканых волокнистых материалов на основе биополимера - полигидроксибутирата. По особенностям макроструктуры (характеру распределения волокон в объеме материала) нетканые материалы можно разделить на 3 условные группы: равномерные, среднеплотные, хаотичные. При этом надмолекулярная структура волокна, не зависимо от типа распределения, практически не меняется. В намем исследовании было показано, что количество поглощенного озона зависит от морфологии нетканого волокнистого материала. При этом с ростом поверхностной плотности нетканого материала прямо пропориионально увеличивается объем поглощенного озона, что свидетельствует об ускорении окислительной деградации.

Ключевые слова: полигидроксибутират, ультратонкие волокна, электроформование, морфология, озон, окисление. 


\title{
INFLUENCE OF MORPHOLOGY OF NONWOVEN ULTRAFIBULAR MATERIALS OF POLYHYROXIBUTIRATE ON THE INTERACTION WITH OZONE
}

\author{
A.A. Olkhov ${ }^{1,2}$, P. M. Tyubaeva ${ }^{1,2}$, A.S. Kurnosov ${ }^{2}$, A.A. Popov ${ }^{1,2}$, \\ V.V. Podmasteriev ${ }^{2}$, A. L. Iordanskii ${ }^{3}$
}

${ }^{1}$ Stremyanny lane 36, Moscow, 117997, Russia. Plekhanov Russian University of Economics.

${ }^{2}$ Kosygina str., 4, Moscow, 119334, Russia. Institute of Biochemical Physics RAS (IBCP RAS).

${ }^{3}$ Kosygina str., 4, Building 1, Moscow, 119991, Russia. Semenov Institute of Chemical Physics RAS.

\begin{abstract}
Samples of non-woven fibrous materials based on a biopolymer - polyhydroxybutyrate - were obtained by electrospinning. According to the features of the macrostructure (the nature of the distribution of fibers in the volume of the material), nonwoven materials can be divided into 3 conditional groups: uniform, medium dense, and chaot$i c$. In this case, the supramolecular structure of the fiber, regardless of the type of distribution, practically does not change. In our study, it was shown that the amount of ozone absorbed depends on the morphology of the nonwoven fibrous material. At the same time, with an increase in the surface density of the nonwoven material, the volume of absorbed ozone directly proportionally increases, which indicates an acceleration of oxidative degradation.
\end{abstract}

Key words: polyhydroxybutyrate, ultrathin fibers, electrospinning, morphology, ozone, oxidation.

\section{Введение}

Недостатком традиционных технологий формования пленочных и волокнистых материалов является использование высокотоксичных растворителей и большого количества технологических добавок, либо высоких температур переработки полимера, что приводит к деструкции макромолекулярных цепей, приводит к накоплению токсичных веществ и тем самым существенно ухудшает биосовместимость готового материала $[1,2]$.

Одним из направлений в области получения функциональных материалов методом электроформования волокна является создание высокопористых полифункциональных материалов для биомедицины, фильтрации, экологии и др. На основе нетканых волокнистых материалов на основе биополимеров полученных методом электроформования уже созданы и разрабатываются инновационные композиционные материалы и конструкции на их основе с многофункциональными свойствами: биосовместимостью, тромборезистентностью, экологической безопасностью, гигиеничностью, биодеградацией в условиях окружающей среды [3].

Наиболее оптимальным по своим свойствам для биомедицинских приложений используется биополимер бактериального происхождения - полигидроксибутират. Он обладает оптимальным комплексом физико-механических и диффузионных свойств, биосовместимостью, биорезорбцией и биодеградацией в окружающей среде на нетоксичные продукты [4]. Изделия и материалы на основе этого полимера применимы для регенерации нервной ткани, в качестве искусственных биорезорбируемых имплантатов, шаблонов для выращивания клеток, матриц контролируемого высвобождения лекарственных веществ и как элемент конструкций для тканевой, и клеточной инженерии [5].

Изделия медицинского и биологического применения подвергаются различным видам стерилизации, что может ускорить процессы естественного старения в процессе эксплуатации изделия. Поэтому в течение последних лет все больший интерес вызывает у ученых изучение воздействия агрессивных сред на старение биополимерных материалов [6-8].

Процессы стерилизации материалов и изделий медицинского назначения зачастую связаны с использованием озонирования $[9,10]$. Озон является сильным окислителем органических веществ, в том числе полимеров и эластомеров. Действие 
озона на полимеры и связанное с ним изменение свойств полимерных материалов интенсивно изучаются, особенно в последние годы. Исследование влияния озона на надмолекулярную и молекулярную структуру биополимеров с целью оптимизации концентрационно - временных параметров процесса озонолиза без ухудшения свойств материалов, является важной и актуальной задачей полимерного материаловедения. Это необходимо как для понимания процессов связывания озона и протекания реакций окисления на поверхности и объеме полимерного материала $[11,12]$.

Следует также отметить, что в виду широкой области применения озона (медицина, химическая промышленность, микроэлектроника и системы водоочистки) требуется разработка методов и материалов для связывания (разложения) избыточного озона. На сегодняшний день эта задача окончательно не решена. Одним из путей её решения может быть применение биополимерных материалов однократного использования.

Цель настоящей работы состоит в изучении воздействия озона на структурную организацию волокнистых материалов на основе ПГБ, полученных методом электроформования.

\section{Объекты и методы исследования}

В работе использовали природный биоразлагаемый полимер полигидроксибутират серии $16 \mathrm{~F}$, полученный методом микробиологического синтеза компанией BIOMER ${ }^{\circledR}$ (Германия): белый мелкодисперсный порошок с размером частиц 5-20 мкм. Молекулярная масса ПГБ $\mathrm{M}_{\mathrm{w}}=2,0610^{5}$ г/моль плотность $\mathrm{d}=1,248$ г $/ \mathrm{cm}^{3}, \mathrm{~T}_{\text {пл }}=177^{\circ} \mathrm{C}$, степень кристалличности - 65 \%. Ультратонкие волокна ПГБ получали методом электроформования (ЭФ). На сегодняшний день единственным высокопроизводительным и апробированным в промышленности методом получения сверхдлинных полимерных нановолокон является электроформование. В основе метода лежит процесс вытягивания тонких полимерных струй под действием электрического поля высокой напряженности с последующим высыханием струи и оседанием в вид

е однородного по длине волокна [13]. Для формования волокон готовили $7 \%$ формовочные растворы ПГБ в хлороформе. Более подробное описание условий формования ультратонких волокон на основе ПГБ содержится в работе [14].

Молекулярную подвижность изучали микрозондовым методом ЭПР. В качестве зонда использовали стабильный нитроксильный радикал 2,2,6,6-тетраметилпиперидин-1-оксил (ТЕМПО). Радикал вводили в волокнистый материал из паров при температуре $25^{\circ} \mathrm{C}$ до концентрации не превышающей $10^{-3}$ моль/л. Регистрацию спектров ЭПР проводили в отсутствии насыщения, что проверяли по зависимости интенсивности сигнала от мощности микроволнового поля. Значения времени корреляции вращения зонда ( $\tau)$ оценивали из спектров ЭПР. Время корреляции определяли по формуле [14]:

$$
\tau=6.65 \cdot 10^{-10} \Delta H^{+}\left(\sqrt{I^{+} / I^{-}}-1\right),
$$

где $\Delta \mathrm{H}^{+}$- ширина компоненты спектра, расположенной в слабом поле, $\mathrm{I}^{+} / \mathrm{I}^{-}$интенсивности компонент в слабом и сильном поле соответственно. Ошибка в определении $\tau$ составляла $\pm 5 \%$.

Геометрию волокнистых материалов исследовали методом электронной микроскопии с помощью сканирующего электронного микроскопа "Hitachi TM-3000" (Япония) при ускоряющем напряжении 20 кV. На поверхность образца нетканого волокнистого материала напыляли слой золота толщиной 100-200 А́.

Исследование образцов методом ДСК проводили на приборе DSC 204 F1 фирмы Netzsch в инертной среде аргона (Ar) со скоростью нагрева $10{ }^{\circ} \mathrm{C} /$ мин. Среднестатистическая ошибка измерения тепловых эффектов составляла $2 \%$.

Исследование взаимодействия озона с нетканым материалом проводили с помощью озонатора, соединенного с колбой, в которую помещали образец на основе ПГБ. В озонаторе газовый поток с установленной концентрацией озона и скоростью потока проходит через закрепленный образец. Кинетику реакции изучали по изменению концентрации озона на выходе из реактора спектральным методом. В устройстве, содержащем детектор (спектрофотометрическую кювету с установленной длинной световой волны $\lambda=254$ нм), регистрируется изменение оптической плотности, свидетельствующее об изменении концентрации озона в газовом потоке. Скорость расхода газа 101,8 мл/мин.

Параметр нетканого волокнистого материала, характеризующий его морфологию - поверхностная плотность $\mathrm{M}_{\mathrm{s}}$, [м²/ г], определяли по формуле:

$$
\mathrm{M}_{\mathrm{s}}=\mathrm{S} / \mathrm{m} \text {, }
$$

где: $\mathrm{S}$ - площадь поверхности нетканого волокнистого материала, м $^{2} ; \mathrm{m}$ - масса нетканого волокнистого материала, г.

\section{Результаты и их обсуждение}

Используя метод электроформования, в работе были получены образцы нетканых волокни- 
стых материалов на основе ПГБ. Все образцы визуально характеризовались неоднородностью в направлении от центра к краю, что связано с уменьшением электростатического поля по мере удаления от капилляра, на конце которого формируется струя формовочного раствора и происходит волокнообразование (рис. 1), можно предположить неоднородность взаимной укладки волокон и связанный с этим градиент плотности материала.

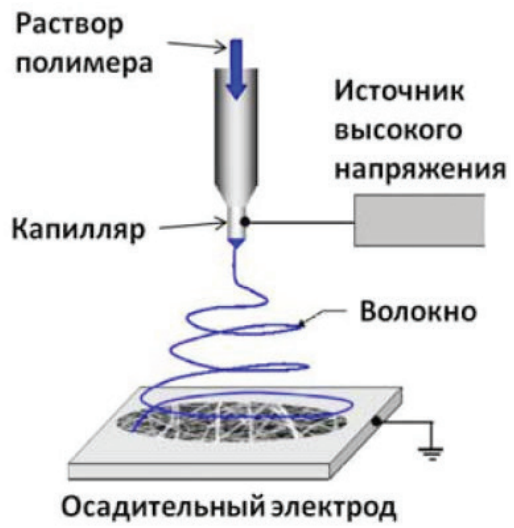

Рис. 1. Схема метода электроформования

Изучение морфологии волокнистых материалов проводили методом электронной сканирующей микроскопии (СЭМ). Внутренняя структура была изучена методами дифференциальной сканирующей калориметрии (ДСК) и электронного па- рамагнитного резонанса (ЭПР). Микрофотографии использовали для определения геометрических характеристик волокна, таких как диаметр, разнотолщинность, коэффициент ориентации волокна, которые позволили оценить равномерность и особенности объемного и поверхностного заполнения нетканого материала, величину поверхностной плотности и др.

Надмолекулярная структура ультратонких волокон ПГБ является определяющим фактором в формировании комплекса свойств материала, обеспечивающих его функциональные свойства. Изучение надмолекулярной структуры и сегментальной подвижности волокнистых материалов проводили методами ДСК и ЭПР.

Термограммы ДСК на рис. 2 показывают, что образцы нетканого материала ПГБ имеют два максимума плавления, которые лежат в различных температурных областях.

Расхождения в показателях температуры плавления становятся наиболее заметными для образцов, подвергнутых циклу нагрев-охлаждение (второй температурный скан). После повторного прогревания одиночные максимумы плавления переходят в максимумы бимодальной формы при 162 и $149{ }^{\circ} \mathrm{C}$. Высокотемпературные пики плавления в результате вторичного прогревания падают более чем на $10{ }^{\circ} \mathrm{C}$, что свидетельствует о снижении совершенства организации кристаллической фазы образцов в результате охлаждения их расплава до комнатной температуры.

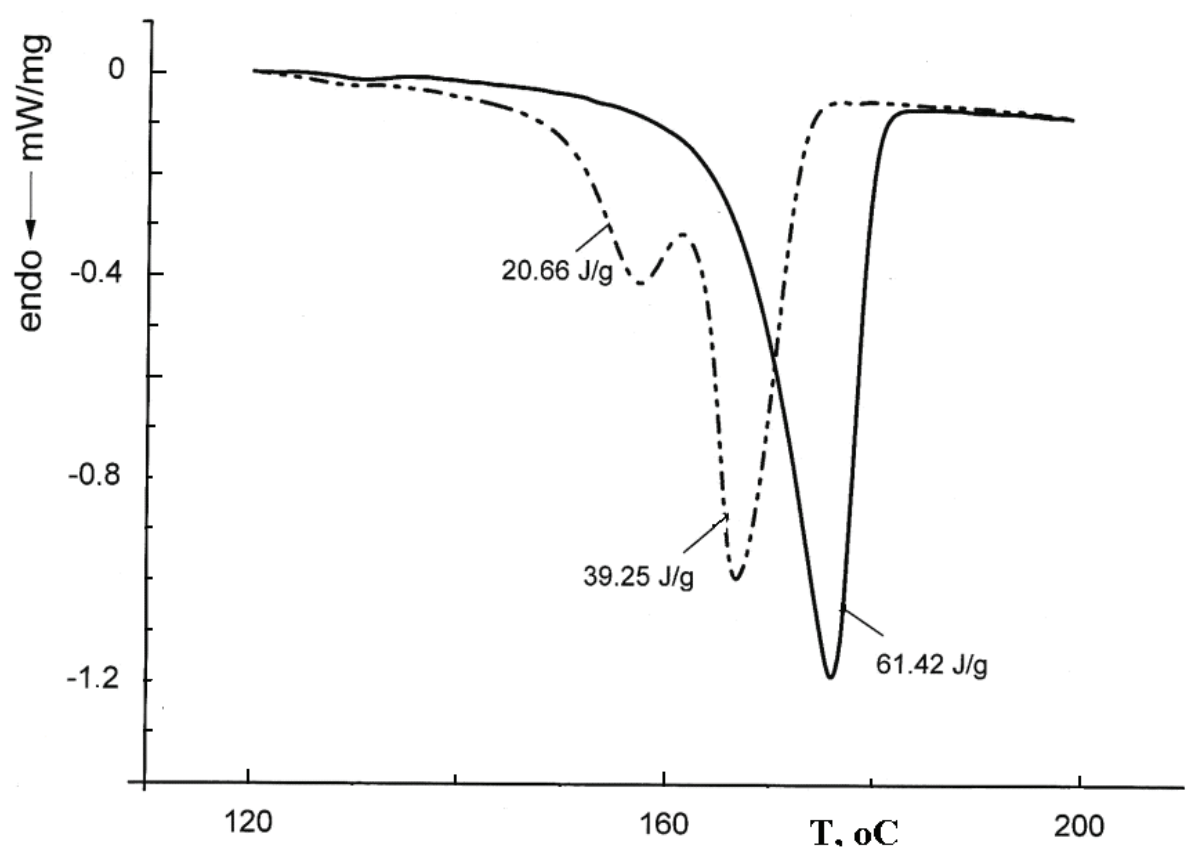

Рис. 2. Термограмма нагревания нетканого волокнистого материала ПГБ: —- первый нагрев; --_--- второй нагрев 
Основные выводы, сделанные в результате количественного рассмотрения термограмм плавления волокнистых матриц ПГБ, сводятся к следующему: однократный прогрев приводят к бимодальному распределению кристаллической фазы на более совершенные и менее совершенные кристаллические области, имеющие разную степень дефектности. Наличие этих двух кристаллических фракций может привести к гетерогенности аморфной межкристаллической фазы ПГБ, более плотной, упорядоченной и менее упорядоченной. Последнее заключение не совсем очевидно и требует дополнительного подтверждения, что будет выполнено методом микрозондовой ЭПР-спектроскопии, который позволяет оценить не только динамические характеристики движения сегментов ПГБ, но и различия в плотностях его аморфной фазы, рассматриваемую как комбинацию более упорядоченных и менее упорядоченных областей аморфной фазы $[15,16]$.

Спектры ЭПР радикала ТЕМРО в матрице, сформированной на основе ультратонких волокон ПГБ, представляют суперпозицию двух индивидуальных спектров, принадлежащих радикалам с различным временем корреляции $\tau_{1}$ и $\tau_{2}$ (рис. 3 ).

Здесь $\tau_{1}$ характеризует сегментальную подвижность в более плотных аморфных областях, $\tau_{2}-$ в менее плотных. Наличие, по крайне мере, двух времен корреляции в аморфной области волокнистых матриц ПГБ свидетельствует о гетерофазном строении межкристаллических областей полимера и согласуется с современной моделью бимодального строения аморфной фазы частично кристаллизующихся полимеров, таких как ПГБ, полилактид и полиэтилентерефталат [17].

Количественный анализ спектров ЭПР был проведен путем их обработки по уравнению, а также из расчета отношений интенсивностей низкополевых пиков, принадлежащих радикалам с замедленной и более быстрой модой движения, $I_{+}{ }_{+}$и $I_{+}^{2}$ соответственно (рис. 3б). В волокнах ПГБ отношение $I_{+}^{1} / I_{+}^{2}$ достаточно значительное и составляет 0,37, что свидетельствует о неравновесном состоянии сегментов полимера в аморфных областях. Кроме того, эффективные значения времени корреляции, соответствующие вращательной подвижности радикала в волокне $\left(0,92 \cdot 10^{-9} \mathrm{c}\right)$, что указывает на более быстрое вращение радикала в аморфной фазе волокон.

Дополнительно к динамическим измерениям были проведены эксперименты по определению концентрации радикала, адсорбированного в волокнах. Расчет, произведенный на основании интегрирования спектров ЭПР показал, что эта концентрация составляла в волокнах $2,9 \cdot 10^{18}\left(6,0 \cdot 10^{-4}\right)$ спин/г (M/л). Эта величина указывает на наличие

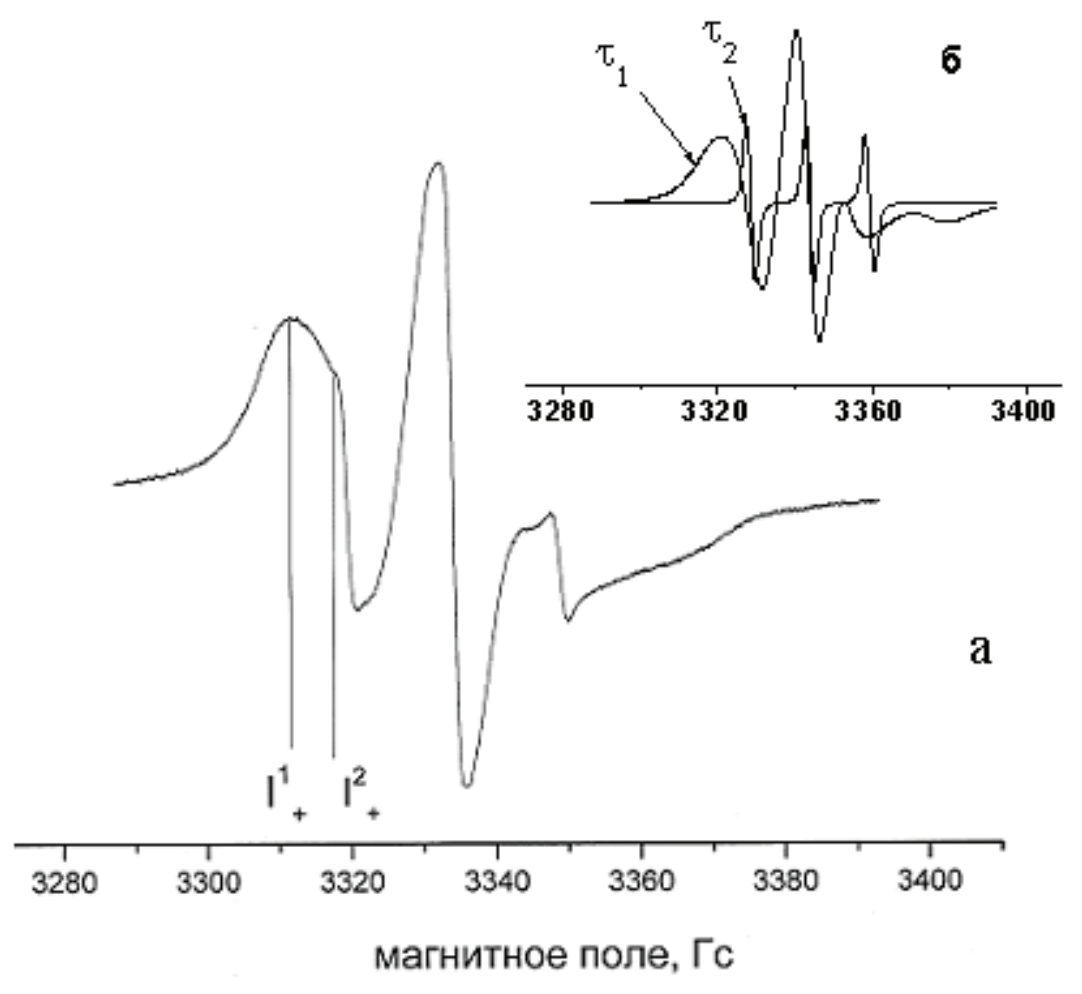

Рис. 3. Спектры ЭПР нитроксильного радикала (а), разложение спектра на медленную $\left(\tau_{1}\right)$ и быструю $\left(\tau_{2}\right)$ популяцию (б) 
небольшого удельного объема полимера, способного вместить радикал, т.е. на наличие более плотной аморфной фазы ПГБ в волокнах. Все полученные закономерности структурообразования характерны для волокон, расположенных по всему периметру образца нетканого материала не зависимо от локализации.

При изучении микрофотографий в нетканом материале были выделены три характерные области с плотной упорядоченной укладкой волокна, смешанной и хаотичной. На рис. 4 представлены типичные области нетканого материала при различном взаимном расположении волокон. Равномерное распределение характеризуется прямыми участками волокон, расположенных под углом около $90^{\circ}$ относительно соседних участков. Хаотичное распределение характеризуется большой спутанностью, извилистостью и переплетениями участков волокон. В среднем распределении присутствуют элементы первых двух. Плотная укладка расположена в центральной области нетканого материала в непосредственной близости от капилляра. Смешанный тип укладки волокна характерен для средней области нетканого материала. Хаотичная укладка волокна характерна для краевых областей нетканого материала, расположенных на большом удалении от капилляра. Поскольку процесс ЭФ основан на вытягивании капли полимерного раствора с помощью электрического поля между отрицательным и положительным электродами, с увеличением расстояния от источника напряжения (капилляра) электрическое поле ослабевает в квадратичной зависимости. При этом меняется плотность укладки волокна, несущего на своей поверхности остаточный электростатический заряд. Как видно на рис. 2 в волокнах ПГБ диаметр меняется в диапазоне 6-12 мкм.

При этом, как было показано выше, структура волокна не зависит от морфологии нетканого материала, то есть от упаковки волокон относительно друг друга. Однако плотность упаковки нетканого волокнистого материала будет оказывать влияние на сорбционно-диффузионные параметры материала для различных паров и газов и, соответственно, приводить к изменению механизма взаимодействия низкомолекулярного вещества с полимером.

Непосредственно в центральной части подложки (см. рис. 1.) происходит образование наиболее плотного слоя. Затем при увеличении расстояния от центра плотность материала падает. По краям формируется наиболее рыхлый нетканый материал. Такая морфология находится в корреляции с падением интенсивности электромагнитного излучения от расстояния в квадратичной зависимости [18].

Такая разница в морфологии нетканых материалов, несомненно, будет влиять на кинетику процессов деградации волокнистых материалов. На основании рассмотрения морфологических особенностей волокнистых нетканых матриц ПГБ на макро- и надмолекулярном уровнях структурной организации можно предположить, что при воздействии агрессивных факторов внешней среды (например, кислород) кинетические зависимости будут зависеть от плотности упаковки (ориентации) волокон в объеме нетканого материала и наличие свободного объема в структуре элементарного волокна (на надмолекулярном уровне) [19, 20].

Поскольку материалы и изделия медицинского назначения подвергаются различным видам стерилизации, в результате высокоэнергетического воздействия которых может образоваться озон, в дальнейшей работе мы исследовали влияние этого агрессивного фактора на структуру нетканых волокнистых материалов. Поэтому на следующем этапе работы мы исследовали взаимодействие озона с неткаными материалами различной степени плотности и упорядоченности.

На рис. 5 представлены типичные зависимости оптической плотности в озонаторе от времени

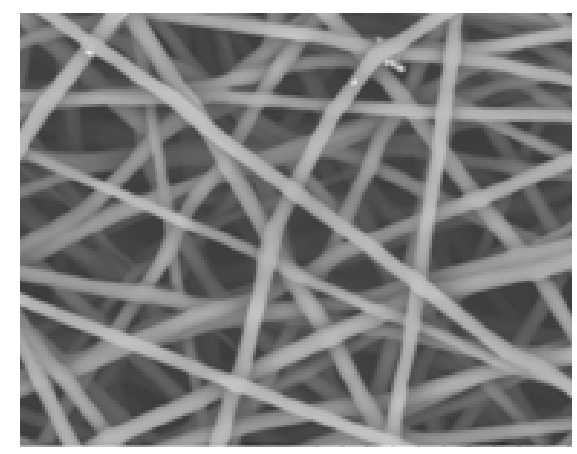

$a$

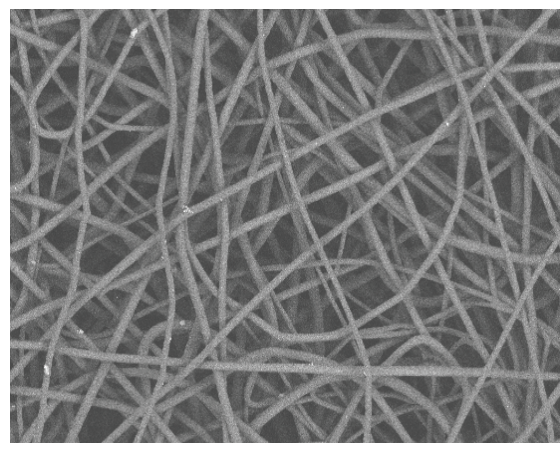

6

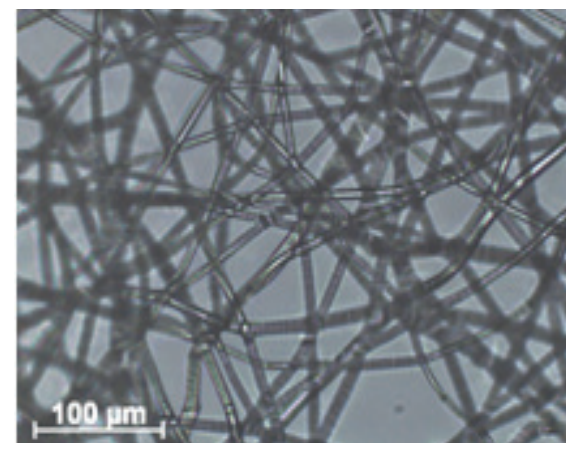

B

Рис. 4. Микрофотографии нетканых волокнистых материалов ПГБ различной морфологии: равномерное (а), среднее (б) и хаотичное (в) распределения 


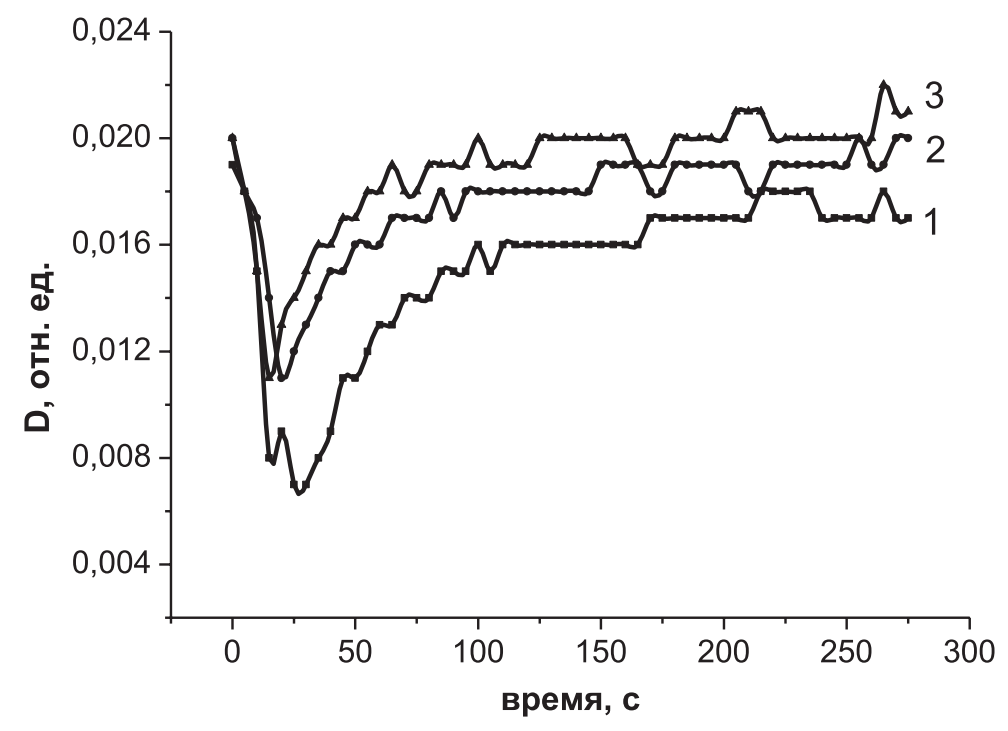

Рис. 5. Зависимости оптической плотности газовой фазы от времени озонирования образцов нетканых волокнистых материалов ПГБ различной морфологии:

равномерные (1), средние (2) и хаотичные (3)

удержания в нем образцов нетканых волокнистых материалов.

Для более полной характеристики влияния озона на структуру волокон проводили регистрацию доли поглощенного газа. Для каждого образца расчетным методом было установлено количество поглощенного озона. На основе значений объема поглощенного газа был установлен ряд зависимостей между структурой материала и способностью образцов реагировать со свободным озоном, который поступал в газовую камеру, где был установлен образец. Ниже представлена типичная за- висимость оптической плотности газа в озонаторе от времени экспозиции образца. Падение оптической плотности в первые секунды озонирования свидетельствует о сорбции газа активной поверхностью волокнистых материалов и протеканию химической реакции. Затем следует диффузия озона в объем волокон и протекание твердофазных реакций взаимодействия полимерных цепей с молекулами озона.

В работе установлены зависимости между структурой материала и показателями поглощения, а именно: между распределением воло-

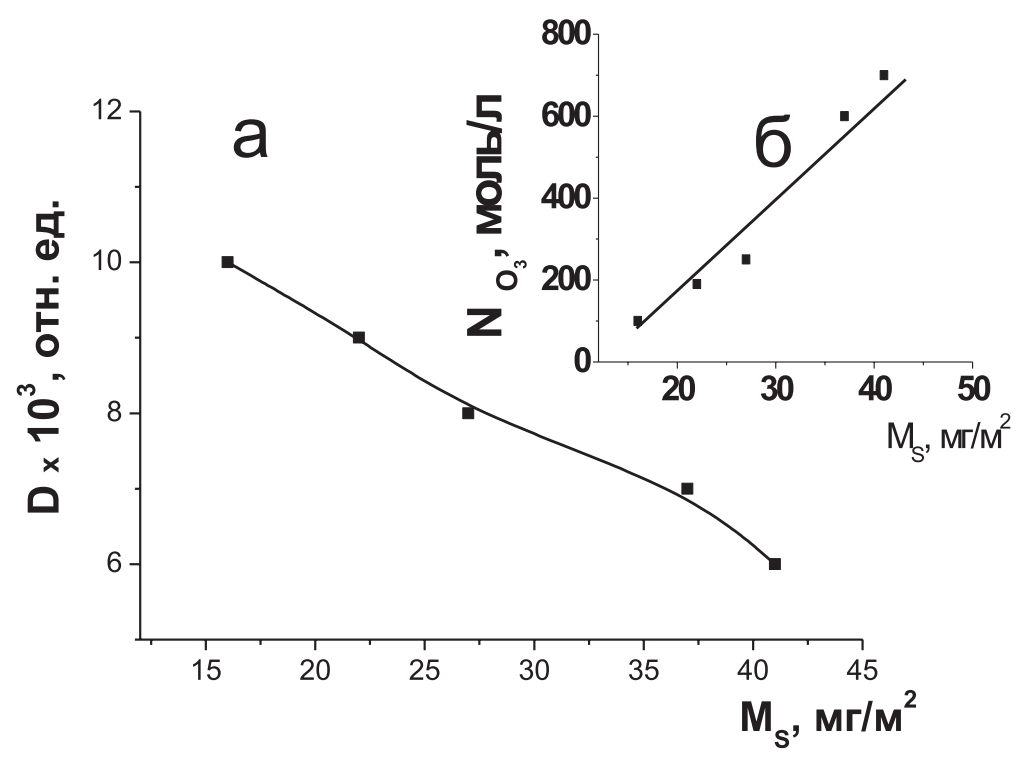

Рис. 6. Зависимость оптической плотности (а) и количества поглощенного озона (б) от величины поверхностной плотности нетканых волокнистых материалов ПГБ 
кон в материале, которое характеризуется поверхностной плотностью материала $\mathrm{Ms}\left[\mathrm{Mг} / \mathrm{M}^{2}\right]$, и оптической плотностью - параметр D (см. рис. 6а). Поверхностная плотность нетканого материала увеличивается с уменьшением среднего расстояния от капилляра. То есть увеличивается количество волокон в единице площади и объема соответствующего участка нетканого материала. При этом средний диаметр волокна менялся незначительно.

Нами было определено, что количество поглощенного озона зависит от морфологии нетканого волокнистого материала. Для этого мы построили зависимость количества поглощенного озона от поверхностной плотности нетканых волокнистых материалов, которая представлена на рис. $6 б$. На основании полученных зависимостей (рис. 6), следует, что увеличение поверхностной плотности нетканого волокнистого материала приводит к росту поглощения озона. Причиной по нашему мнению является увеличение удельной поверхности волокнистого материала, приводящее к повышению контакта полимера с молекулами озона.

\section{Заключение}

Образцы нетканых волокнистых материалов, полученных методом электроформования, по особенностям макроструктуры (характеру распределения волокон в объеме материала) можно разделить на три условные группы: равномерные, среднеплотные, хаотичные. При этом надмолекулярная структура волокна, не зависимо от типа распределения, практически не меняется. В нашем исследовании было показано, что количество поглощенного озона зависит от морфологии нетканого волокнистого материала. При этом с ростом поверхностной плотности нетканого материала прямо пропорционально растет объем поглощенного озона, что свидетельствует об ускорении окислительной деградации.

\section{Лumepamypa}

1. Averous L., Pollet E. Journal of Green Energy and Technology. 2012. V. 2. №4. P. 28-31.

2. Volova T.G. Polym. Degrad. Stab. 2010. V. 95. № 12. P. 2350-2359.
3. Perale G., Hilborn J. Bioresorbable Polymers for Biomedical Applications. Amsterdam; Boston; London: Elsevier, 2017.

4. Бояндин А.Н. Прикладная биохимия и микробиология. 2012. Т. 48. № 1. С. 35-44.

5. Ольхов А.А., Карпова С.Г., Староверова О.В., Кучеренко Е.Л., Ищенко А.А., Иорданский А.Л. Химические волокна. 2016. № 4. С. 28-36.

6. Жила Н.О. Журнал Сибирского федерального университета. Биология. 2012. № 5(2). С. 210-215.

7. Тертышная Ю.В. Высокомолекулярные соединения. 2013. Т. 55. №3. С. 362-368.

8. Akaraonye E. Biotechnology journal. 2012. T. 7. №2. P. 293-303.

9. Лунин В.В., Попович М.П., Ткаченко С.Н. Физическая химия озона, М.: Изд. МГУ им. М.В. Ломоносова, 1998, $480 \mathrm{c}$.

10. Разумовский С.Д., Заиков Г.Е. Озон и его реакции с органическими соединениями (кинетика и механизм). М.: Наука, 1974, 322 с.

11. Meshkova I.N., Kiseleva E.V., Krasheninnikov V.G., Shchegolikhin A.N. Polymer Science, Series B. 2017. V. 59. P. 62-68.

12. He G.-J., Yuan B.-Y., Zheng T.-T., Zhu W.-l., Yin X.-C. RSC Adv. 2017. V. 7. P. 22531-22539.

13. Филатов Ю.Н. (Электроформование волокнистых материалпроцесс) / Ю. Н. Филатов. М. : Нефть и Газ, 1997 г. 297 с.

14. Karpova S.G., Iordanskii A.L., Motyakin M.V., Ol'khov A.A., Staroverova O.V., Lomakin S.M., Shilkina N.G., Rogovina S.Z., Berlin A.A. Polymer Science, Series A. 2015. V. 57. №2. P. 131-138.

15. Iordanskii A.L., Kamaev P.P. Polymer Science. Series B. 1998. V. 40. № 1-2. P. 8.

16. Ольхов А.А., Камаев П.П., Маркин В.С., Косенко Р.Ю., Гольдитрах М.А., Иорданский А.Л. Влияние способа формования на морфологию и диффузионные свойства пленок на основе полигидроксибутирата // Все материалы. Энциклопедический справочник. 2015. № 7. С. 30-39.

17. Di Lorenzo M.L., Gazzano M., Righetti M.C. Macromolecules. 2012. V. 45. P. 5684.

18. Rouquerol F., Rouquerol J., Sing K.S.W., Llewellyn P., Maurin G. Adsorption by Powders and Porous Solids. Principles, Methodology and Applications (Second Edition), Elsevier Ltd. Academic Press. 2012. 646 p. ISBN 978-0-08-097035-6.

19. Sadi R.K. Polym. Degrad. Stab. 2010. T. 95. № 12. P. 2318-2327.

20. Karpova S.G., Ol'khov A.A., Lobanov A.V., Popov A.A., Iordanskii A.L. Nanotechnologies in Russia. 2019. V. 14. N. 3-4. P. 132-143. 